Article

\title{
Wicked Problems of Smart Cities
}

\author{
Johan Colding ${ }^{1,2,3, *(\mathbb{C})}$, Stephan Barthel ${ }^{1,2}(\mathbb{C})$ and Patrik Sörqvist ${ }^{1}$ \\ 1 Department of Building Engineering, Energy Systems and Sustainability Science, University of Gävle, \\ Kungsbäcksvägen 47, 80176 Gävle, Sweden; Stephan.Barthel@hig.se (S.B.); Patrik.Sorqvist@hig.se (P.S.) \\ 2 Stockholm Resilience Centre, Stockholm University, Kräftriket 2B, 11419 Stockholm, Sweden \\ 3 The Beijer Institute of Ecological Economics, Royal Swedish Academy of Sciences, Box 50005 Stockholm, \\ Sweden \\ * Correspondence: Johan.Colding@hig.se
}

Received: 5 September 2019; Accepted: 5 November 2019; Published: 7 November 2019

check for updates

\begin{abstract}
It is often uncritically assumed that, when digital technologies are integrated into the operation of city functions, they inevitably contribute to sustainable urban development. Such a notion rests largely on the belief that Information and Communication Technology (ICT) solutions pave the way for more democratic forms of planning, and that 'smart' technological devices result in a range of environmental benefits, e.g., energy efficiency and the mitigation of global warming. Drawing on the scientific literature that deals with 'smart cities', we here elaborate on how both propositions fail to consider drawbacks that could be characterized as 'wicked', i.e., problems that lack simplistic solutions and straightforward planning responses, and which often come about as 'management surprises', as a byproduct of achieving sustainability. We here deal with problems related to public choice constraints, 'non-choice default technologies' and the costs of automation for human learning and resilience. To avoid undemocratic forms of planning and too strong a dependence on non-choice default technologies, e.g., smart phones, we recommend that planners and policy makers safeguard redundancy in public-choice options by maintaining a wide range of alternative choices, including analog ones. Resilience thinking could help planners deal more effectively with the 'wickedness' of an increasingly hyper-connected society.
\end{abstract}

Keywords: smart city; wicked problems; public choice constraints; automation; default technologies; resilience

\section{Introduction}

In the last decade, digital technological solutions have been launched, as a way to make our cities more sustainable. While technologies can improve the efficiency of material utilization, remove pollution and contaminants from the natural environment, and help us monitor and understand our effect on the natural environment [1], they are also a central component of environmental problems [2]. Although eco-friendlier technologies have recently begun to deal with climate change, public attitudes have changed very little, despite a steady increase in alarming climate facts [3]. When it comes to climate change, researchers suggest that humans already have contravened the Earth's 'safe operating space' [4-6].

There exists a myriad of definitions of smart cities in the literature (see, e.g., [7]), and not all of these rest on the digital society, but on other premises, that could create more intelligent ways of interacting with and governing a local community, town or city. By a smart city (SC), in this paper, we mean "a city in which Information and Communication Technology (ICT) is merged with traditional infrastructure, coordinated and integrated using new digital technologies" [8]. Such a network of technological devices includes, e.g., home appliances, and other items embedded with software electronics, sensors, actuators, and networks [9]. 
In this paper, we discuss both the potential and the drawbacks of ICT and smart city models for mitigating climate change and environmental problems at large. It is often assumed that the digitalization of increasing amounts of services and functions in a city inevitably contributes to sustainable urban development [10]. Such an assumption rests largely on two propositions: first, that ICT solutions can pave the way for more democratic forms of urban planning and governance regimes; second, that smart technological devices will result in cleaner technologies (e.g., energy efficiency) and, in this way contribute, to the mitigation of global warming [11]. Drawing on the scientific interdisciplinary literature, we here discuss how both propositions have inherent limitations that, to a greater or lesser extent, could be characterized as 'wicked'; that is, problems that lack simplistic solutions and straightforward planning responses [12].

There exist a number of studies that have discussed both the environmental and democratic aspects of smart-city development [13-16]; however, we are not aware of any paper that has discussed the wickedness of these problems, in particular in relation to human behavior. This paper begins with a brief discussion of how ICT may be part of the solution to some well-known climate change and resource issues with behavioral roots. Thereafter, we discuss the wickedness of introducing ICT solutions to these environmental problems. Specifically, we address three aspects of this: public choice constraints, 'non-choice default technologies', and the costs of automation to human learning and resilience. Finally, we highlight the important role that redundancy plays in managing complex adaptive systems (CAS) and conclude by proposing that planners and policymakers build smarter cities whilst paying greater attention to resilience thinking.

\section{ICT as Part of the Solution}

A central tenant of climate change mitigation is the promotion of more environmentally friendly technological inventions. It is important to recognize that human behavior changes with technological change. For example, energy conservation by the development of new technologies may result in the phenomenon known as 'energy rebound' [17], which was first observed by Jevons (1865), who argued that the enhanced efficiency of coal-driven steam engines would increase, not decrease, coal dependency, and therefore contribute to more rapid depletion of the coal reserve. When the use of a resource is made more efficient in free market economies, its price usually drops-a situation that may result in increased demand and consumption of the resource [18]. This, in turn, can 'take-back' all the efficiency gains achieved $[18,19]$.

There are also secondary effects of reducing energy costs through efficiency, in that consumers may buy more products or choose larger, more powerful electronic equipment [19]. Hence, energy-saving technology often leads (in the long term) not to a reduction, but, instead, to an increase in energy use, an argument supported by the historical record for most of the last century. Part of the explanation for this behavior is people's tendency to justify environmentally harmful behavior upon acquiring energy-efficient equipment and fuels (e.g., [20]). The vast majority of these undesirable behaviors are closely related to a phenomenon called 'negative spillover'; when people do something they experience as pro-environmental in one area, they tend to do more harmful things in another [21].

Energy rebounding and negative spillover can be explained by the mental heuristic that people apply to seek a balance between 'good' and 'bad' behavior [22,23]. This balancing heuristic has its evolutionary roots in governing social exchange (give and take in relationships) and works well for that purpose, but when the same balancing heuristic is applied to environmental issues (to balance 'environmentally friendly' and 'harmful' behavior) it leads to systematically erroneous thinking and potentially harmful behavior [22]. For example, people tend to think that small emission cuts can compensate for past emission rates and, thus, reduce the atmospheric concentration of carbon dioxide $\left(\mathrm{CO}_{2}\right)$ altogether, while, in reality, $\mathrm{CO}_{2}$ concentration keeps on accumulating [24].

Consumer policy interventions, and new technology and business models, such as eco-labeling and carbon offset systems, that are launched to guide behavior towards more pro-environmental outcomes, may backfire due to negative spillover, energy rebound and the balancing heuristic. These 
are especially likely when people are made aware that their behavior is regarded as 'pro-environmental', or when the behavior is more costly than the harmful behavior (such as when consumers pay more money for an eco-labeled product in the grocery store).

A potentially more successful tool for behavioral change is the use of nudging and defaults, in particular in the context of changes in the physical environment, that shape behavioral flow in a more environmentally friendly direction. In a decision theoretical context, a default refers to the option which the user ends up with if they do not make an active choice. In social settings, for example, individual choice may be adopted unconsciously as a social default effect (i.e., normative choice)—a situation where people mimic what others are doing [25]. In the affordance literature, different types of qualities of the physical environment often serve as default situations, to nudge people toward a particular behavior [26].

Experiments and observational studies in psychology show that, among the set of options that agents choose from, the default option is the option the person will select most frequently, acting as if he or she is doing nothing. This could be explained by the fact that, if an agent is indifferent or experiences a conflict between options, it may involve too much cognitive effort to base a choice on explicit evaluations. In that case, the person might disregard the evaluations and choose according to the default heuristic instead, which simply states "if there is a default, do nothing about it" [27].

Thus, ICT defaults of the smart city have the potential to shape people's behavior in desirable ways that information campaigns and policy interventions cannot, and can help people make choices that are better for them and for society in large. Default rules of various sorts (e.g., double-sided printing) can indeed foster pro-environmental behavior [28]. A corresponding, non-digital example is reducing the size of food plates, which can significantly reduce the amount of food left on the plate and thereby reduce food waste [29]. However, these defaults are associated with other drawbacks.

\section{Wicked Problems of ICT}

\subsection{The Democracy Problem of 'Non-Choice Default Technology' (NDT)}

Sophisticated personal devices are important sources of sensory data and crowdsourcing. Technology adoption (and diffusion) entails the broad public acceptance of a new product or innovation, according to demographic and psychological characteristics [30]. The technological adoption of, for example, smart phones and inexpensive tablet computers, is performing increasing amount of functions in the digital smart city. Currently, almost two-thirds of the human global population has a mobile phone, and more than half of the world's population uses smartphones. An increasing number of home routines, such as different, remotely controlled electronic home devices, are increasingly run by smartphones in the smart city, as well as a mounting quantity of public services, such as cashless transaction apps for day-to-day payments, smartphone-maneuvered parking meters, different kinds of Medicare services, and so on.

It is important to recognize that, with the dramatic increase in smartphones and smartphone-maneuvered services, comes a subsequent reduction of alternatives, such as payments by way of credit card or cash. This, indeed, has important ramifications for public choice. Eric Fromm, in his book Escape from Freedom [31], argued that humans are always fraught with the dilemma of making active choices. To avoid such dilemmas, humans often leave it to others to make choices on their behalf. In this way, Fromm argued that human beings avoid the responsibility or freedom of making personal and active choices. Fromm distinguished between 'freedom to' (positive freedom) and 'freedom from' (negative freedom), with the former signifying the liberty to spontaneously participate in creative acts and the latter referring to liberation from restrictions such as social conventions and norms. With this view, Fromm's proposition is in line with the notion of choice default discussed above.

When a technology or technological device, such as the smartphone, becomes too dominant in performing daily tasks, and does not allow for other alternatives or supplementary options, we here refer to it as a 'non-choice default technology' (NDT). One example of an NDT is the total dependence 
of farmers on a single type of genetically modified crop and a specific, tailor-made pesticide. Such tight interdependencies can have devastating social consequences [32]. In situations where NDTs are increasingly used to run daily affairs in a city, people are more or less forced to use the technology, whether they like it or not, because the alternative is highly costly for the individual in terms of finding adequate alternative solutions, if at all possible. Similarly, the technology (i.e., the smartphone) is a profit-boosting entity for its producers and suppliers, which, in turn, is tantamount to privatization of public choice, due to the fact that private interests receive all the revenues from the NDT. This could, in fact, be regarded as a democracy problem, but has not received enough attention in the scientific literature. On a similar note, defaults can also be used to help businesses profit from consumers, sometimes by prompting people to choose things that are not in their best interest. This raises concerns regarding how to ensure defaults are used ethically and responsibly.

\subsection{Participatory Sensing and Public Choice Constraints}

One of the key elements of a democracy consists of the active participation of people "as citizens" in politics and civic life [33]. Local participation in multiple forms is also an important tenet of sustainable development [34], and is often presented as an alternative to 'top-down' planning and development. One example of a more bottom-up form of planning is 'collaborative planning', that involves multi-stakeholder planning scenarios, and is an approach used to resolve and mediate stakeholder disagreements in various planning situations [35]. Community engagement is often purported as an outcome of smart cities [36], where planners can more optimally integrate and synchronize views among a range of stakeholders within a community, town or city, as well as minimize potential conflict between opposing parties and interests in the decision-making process.

The SC-framework is often launched as a participatory planning tool, due to its dual role of participatory sensing, in which citizen's big data and advice are used in the design of a city $[8,37,38]$. Big data analytics have a huge potential to enhance smart city services; however, the combination of the IoT and Big Data is still an immature, unexplored research avenue, with new challenges for achieving the goal of the smart city [39]. For example, recent advances in Geographic Information Systems (GIS), Web 2.0 technologies, and augmented reality technology have the potential to improve public participation [40,41]. This includes Public Participation GIS (PPGIS), with the potential to promote community participation in planning, design and management $[37,38,42]$. The involvement of citizens and other stakeholders in the planning process can be seen as an extension of the democratic process and may ensure that plans are more widely accepted by city residents [43]. Moreover, citizens' knowledge [44] provides a rich source of updated information, with the potential to improve the quality of analysis of urban space, compared to traditional forms of spatial planning data [41].

Public participation by way of ICT could, however, be quite problematic in democratic terms. While it can become a resource for marginalized groups, it may also lead to opposite outcomes [45]. For instance, Townsend [46] argues that, in cities in the developing world, it may cause a permanent offloading of government responsibilities, disallowing poorer communities to have a voice in city planning. Also, Tilly and Wood [47] claim that social movements could become even more biased toward the more privileged members, who have greater access to the Internet.

The difficulties encountered by participants in expressing their views and ideas through the use of ICTs is another well-documented problem, commonly referred to as the 'digital divide' - a term coined to describe the gap between the 'haves' and 'have-nots' in the Internet age [48]. Scholars have long analyzed the effect of unequal Internet access [48,49]. The work of Robinson et al. [50] makes a useful distinction between first-level digital disparities and second-level digital inequalities, with the former signifying accessibility to the Internet, and the latter being related to the skills, participation, and efficacy of the users. A first-level disparity that can be considered a democratic dilemma is the fact that there exists a sizeable proportion of the human population that does not have access to the Internet. As of 2014, some 14\% of the adults in the United States did not use the Internet [50], and about $15 \%$ of Swedes are not using the Internet, with non-users found in all age groups, even among 
the young [51]. A distinguishing factor for many of the non-users is their negative attitude towards trying and testing new technological equipment and services [52].

Second-level digital inequalities can affect an even greater proportion of individuals in a population, even those that are technically skilled. The constant updating of apps and new compatible models of smart phones requires cognitive skills (e.g., memory and problem-solving activities) that decline with the age of an individual $[53,54]$. While smartphones and other mobile technologies can augment human cognition, motoric skills, e.g., the handling of the touch screen interface, also becomes more difficult with age [55]. Hence, when ICT is increasingly merged and coordinated with traditional infrastructure in a city, it risks further marginalizing individuals and groups that find it difficult to use digital technologies, and those that refuse to use these technologies for various reasons ([51].

\subsection{Automation Deprives Learning}

Technological automation can potentially relax everyday life in various ways; smart fridges can order food to the door as soon as they run out of something, and self-driving cars can free time for work when commuting. A downside of automatic systems is that they make it difficult for people to understand their own environmental impact, because they do not experience and understand the links between their own behavior and its consequences. The geographical and temporal distances between behavior and environmental consequences are typically large, which makes it difficult for people to grasp the relationship. A challenge is, therefore, to reinforce these relationships, by making them salient to the user of smart systems. Even if this challenge is overcome, however, automation deprives people of the spontaneous learning of skills that becomes necessary when a technological system fails.

Technological advances could even have direct, negative effects on memory and learning. The fact that most information is just a few computer clicks away appears to make people less likely to store that information properly in memory [56]. This 'digital amnesia' phenomenon has been difficult to replicate in subsequent studies [57], but the cost-benefit trade-off between automation and learning is well established [58]. When automation increases, situational awareness decreases, as well as the learning of manual skills. Regarding the extent to which automation also impairs learning of episodic and semantic information, search engines can come with some surprising costs to society, in particular since higher cognitive skills (e.g., the ability to interpret, draw conclusions, make syntheses and comprehend) partly rest on information stored in memory [59]. In short, digitalization and automation can potentially make people dumber.

When systems break down, such as when the automatic controls of cars malfunction, or when automatic home heating systems fail during winter, people must instead rely on acquired skills. From a macro perspective, smart city models and ICT may prevent manual skills becoming 'hardwired' into the human population's common knowledge. Therefore, relying heavily on fully automatic systems is risky and suboptimal from a resilience perspective.

\section{Creating Redundancy in Smart-City Development to Deal with Wicked Problems}

As discussed above, overuse of ICT may result in a number of wicked problems associated with 'non-choice default technologies', public choice constraints and costs to human learning. While it might be difficult to find adequate solutions to effectively deal with wicked problems, we argue here that the political-economic elites that prescribe SC-development as a way to build more inclusive and sustainable cities should pay more attention to resilience principles when designing and creating the digital city [51]. While it might be difficult for local governments to govern and manage smart cities on behalf of the market, partly because the socio-technical regime operates across jurisdictional boundaries, and exists in "globalized networks of capital, knowledge, people, skills, and resources" [1], the nation state still commands notable financial and organizational resources to steer SC-development towards more resilient ends. For example, the state still remains the foundation of civil authority on the international stage, and possesses established democratic structures for collective decision-making [2]. Hence, it is the responsibility of the state and its federal and local administrative bodies to assure 
that a truly smart city avoids the wicked problems that we have described in this paper. No doubt, these problems are more prolific than conveyed herein, and will likely multiply as more and more city-functions become digitalized [9].

Given the difficulty of detecting wicked problems before they occur, as they often evolve as 'management surprises' (sensu [60]), resilience thinking could be a viable planning approach when designing smarter digital cities. The resilience approach is increasingly winning ground among policy-makers and academia as a means of dealing with the 'wickedness' of today's hyper-connected society $[61,62]$. Resilience thinking can be used as a lens of inquiry for probing both expected and unexpected management surprises, and for studying different developmental pathways and potential thresholds in complex adaptive systems [63]. In this way, resilience thinking represents a framework for urban policy-makers and planners that can be used to identify, probe and deal with wicked problems [62]. Other examples of approaches that could be used in urban planning to detect wicked problems include reflective interpretive policy analysis [64], triangulation and critical theory [65], and 3-D models [40].

One of the key principles of building resilience in complex adaptive systems is 'redundancy'. Functional redundancy, or the presence of multiple components that can perform the same function, can provide 'insurance' within a system, by allowing some components to compensate for the loss or failure of others. Systems that draw on functional redundancy are generally more resilient to various kinds of disturbance and surprises than systems with few components $[66,67]$. Redundancy is even more effective if the components providing the redundancy also react differently to different kinds of disruptions and disturbance (response diversity) [68]. The sayings 'don't put all your eggs in one basket' or 'don't spend all your money on one stock' are well-known redundancy recommendations in economics. Redundancy, however, tends to be ignored in management situations where efficiency, optimization, predictability and reduction of variation are aimed for [60].

\section{Concluding Remarks}

As elaborated upon in this paper, the integration of digital technologies in the operation of city functions and traditional infrastructure does not automatically contribute to sustainable urban development. As every new digital technology entails an array of new relationships to manage, the sheer volume of detail in our daily routines becomes multiplied. Many problems that people have today can be traced to unmanageable complexity-a phenomenon that arises from the tendency to require too much of the devices being managed [69]. Smart-city proponents, however, often claim that ICTs will make our lives easier to live and our cities more sustainable. As highlighted herein, we caution against such simplistic proclamations, especially in smart-city development aiming for increased levels of efficiency by reducing alternative options in the operation and functioning of the city. As probed herein, SC development is fraught with problems that, in their broadest sense, can be characterized as 'wicked'. Examples dealt with here include public choice constraints, non-choice default technologies and costs to spontaneous, as well as deliberate, skill learning, fashioned within the common knowledge of the human population. These problems should be considered in the planning and design of more inclusive and resilient cities.

As a policy recommendation, we urge urban practitioners and policy makers to be more meticulous in making the digital smart city more humane and resilient. Designers of SCs should strive to build redundancy into the options affecting people's daily affairs in the digital city, and avoid situations where non-choice default technologies become too dominant. Creating more inclusive cities (i.e., 'socially smarter' cities) should start with safeguarding alternatives for people that are digitally marginalized, e.g., elderly people and individuals that, for various reasons, cannot, or are unwilling to, use digital technologies. Since we do not know beforehand which technological solutions hold the most potential, we need to accelerate the development of alternatives to the smartphone-maneuvered society [2]. Such alternatives can include anything from the upkeep of analog alternatives such as cash, tokens, keys, or similar physical devices, to digital alternatives, such as credit cards. Since various technological 
solutions will produce different blends and allocations of social goods and ills, society as a whole need to actively nurture redundancy in the name of democracy.

We are already witnessing increasing signs of unmanageable complexity when it comes to securing ICT systems, representing but one example of problems arising at a much faster pace than our ability to solve them. With a likely increase in climate-change propelled hazards, as well as cyber-security attacks, we need to nurture analog alternatives to create redundancy in our cities. One can only imagine the devastating outcomes that could arise with more future severe weather events. When more and more of a city's services and functions become digitalized, cities too become increasingly prone to natural perturbations $[70,71]$ and human vulnerability increases.

Author Contributions: Conceptualization, J.C. and S.B.; methodology, J.C.; formal analysis, J.C., S.B. and P.S.; writing-original draft preparation, J.C.; writing—review and editing, J.C., S.B. and P.S.

Funding: Johan Colding's, Stephan Barthel's and Patrik Sörqvist's work have been funded by the Department of Building Engineering, Energy Systems and Sustainability Science at the University of Gävle. Johan Colding's work has also partly been funded through a research grant (reference number: 2017-00937) received from the Swedish Research Council for Environment, Agricultural Sciences and Spatial Planning (FORMAS). Stephan Barthel's work has also been partly funded through a research grant (reference number: 2016- 011932) received from the Swedish Research Council for Environment, Agricultural Sciences and Spatial Planning (FORMAS). We also would like to thank the Beijer Institute of Ecological Economics, and the Stockholm Resilience Centre for funding this work.

Conflicts of Interest: The authors declare no conflict of interest. The funders had no role in the design of the study; in the collection, analyses, or interpretation of data; in the writing of the manuscript, or in the decision to publish the results.

\section{References}

1. Smith, A.; Stirling, A. The Politics of Social-ecological Resilience and Sustainable Socio-technical Transitions. Ecol. Soc. 2010, 15, art11. [CrossRef]

2. Payne, A. Key Debates in New Political Economy; Routledge: London, UK, 2006; ISBN 9780203965450.

3. Stoknes, P.E.; Randers, J. What We Think about When We Try Not to Think about Global Warming: Toward a New Psychology of Climate Action; Chelsea Green Publishing: White River Junction, VT, USA, 2015; ISBN 9781603585835.

4. Rockström, J.; Steffen, W.; Noone, K.; Persson, A.; Chapin, F.S.; Lambin, E.F.; Lenton, T.M.; Scheffer, M.; Folke, C.; Schellnhuber, H.J.; et al. A safe operating space for humanity. Nature 2009. [CrossRef]

5. Steffen, W.; Rockström, J.; Richardson, K.; Lenton, T.M.; Folke, C.; Liverman, D.; Summerhayes, C.P.; Barnosky, A.D.; Cornell, S.E.; Crucifix, M.; et al. Trajectories of the Earth System in the Anthropocene. Proc. Natl. Acad. Sci. USA 2018, 115, 8252-8259. [CrossRef] [PubMed]

6. Figueres, C.; Schellnhuber, H.J.; Whiteman, G.; Rockström, J.; Hobley, A.; Rahmstorf, S. Three years to safeguard our climate. Nature 2017, 546, 593-595. [CrossRef] [PubMed]

7. Mora, L.; Bolici, R.; Deakin, M. The First Two Decades of Smart-City Research: A Bibliometric Analysis. J. Urban Technol. 2017. [CrossRef]

8. Batty, M.; Axhausen, K.W.; Giannotti, F.; Pozdnoukhov, A.; Bazzani, A.; Wachowicz, M.; Ouzounis, G.; Portugali, Y. Smart cities of the future. Eur. Phys. J. Spec. Top. 2012, 214, 481-518. [CrossRef]

9. Colding, J.; Colding, M.; Barthel, S. The smart city model: A new panacea for urban sustainability or unmanageable complexity? Environ. Plan. B Urban Anal. City Sci. 2018, 239980831876316. [CrossRef]

10. Ahvenniemi, H.; Huovila, A.; Pinto-Seppä, I.; Airaksinen, M. What are the differences between sustainable and smart cities? Cities 2017, 60, 234-245. [CrossRef]

11. Malmodin, J.; Lundén, D.; Moberg, Å.; Andersson, G.; Nilsson, M. Life Cycle Assessment of ICT. J. Ind. Ecol. 2014, 18, 829-845. [CrossRef]

12. Rittel, H.W.J.; Webber, M.M. Dilemmas in a general theory of planning. Policy Sci. 1973, 4, 155-169. [CrossRef]

13. Luque-Ayala, A.; Marvin, S. Developing a critical understanding of smart urbanism? Urban Stud. 2015, 52, 2105-2116. [CrossRef]

14. March, H.; Ribera-Fumaz, R. Smart contradictions: The politics of making Barcelona a Self-sufficient city. Eur. Urban Reg. Stud. 2016, 23, 816-830. [CrossRef] 
15. Hollands, R.G. Critical interventions into the corporate smart city. Cambridge J. Reg. Econ. Soc. 2015, 8, 61-77. [CrossRef]

16. Viitanen, J.; Kingston, R. Smart Cities and Green Growth: Outsourcing Democratic and Environmental Resilience to the Global Technology Sector. Environ. Plan. A Econ. Sp. 2014, 46, 803-819. [CrossRef]

17. van den Bergh, J.C.J.M. Energy Conservation More Effective with Rebound Policy. Environ. Resour. Econ. 2011, 48, 43-58. [CrossRef]

18. Kramers, A.; Höjer, M.; Lövehagen, N.; Wangel, J. Smart sustainable cities-Exploring ICT solutions for reduced energy use in cities. Environ. Model. Softw. 2014, 56, 52-62. [CrossRef]

19. Herring, H.; Roy, R. Technological innovation, energy efficient design and the rebound effect. Technovation 2007, 27, 194-203. [CrossRef]

20. Tiefenbeck, V.; Staake, T.; Roth, K.; Sachs, O. For better or for worse? Empirical evidence of moral licensing in a behavioral energy conservation campaign. Energy Policy 2013, 57, 160-171. [CrossRef]

21. Truelove, H.B.; Carrico, A.R.; Weber, E.U.; Raimi, K.T.; Vandenbergh, M.P. Positive and negative spillover of pro-environmental behavior: An integrative review and theoretical framework. Glob. Environ. Chang. 2014, 29, 127-138. [CrossRef]

22. Sörqvist, P.; Langeborg, L. Why People Harm the Environment Although They Try to Treat It Well: An Evolutionary-Cognitive Perspective on Climate Compensation. Front. Psychol. 2019, 10, 348. [CrossRef]

23. Sörqvist, P.; Langeborg, L. Hurting the world you love. New Sci. 2019, 241, 24-25. [CrossRef]

24. Holmgren, M.; Kabanshi, A.; Langeborg, L.; Barthel, S.; Colding, J.; Eriksson, O.; Sörqvist, P. Deceptive sustainability: Cognitive bias in people's judgment of the benefits of $\mathrm{CO} 2$ emission cuts. J. Environ. Psychol. 2019, 64, 48-55. [CrossRef]

25. Huh, Y.E.; Vosgerau, J.; Morewedge, C.K. Social Defaults: Observed Choices Become Choice Defaults. J. Consum. Res. 2014, 41, 746-760. [CrossRef]

26. Chemero, A. Radical Embodied Cognitive Science; The MIT Press: Cambridge, MA, USA, 2009.

27. Gigerenzer, G. Why Heuristics Work. Perspect. Psychol. Sci. 2008, 3, 20-29. [CrossRef] [PubMed]

28. Sunstein, C.R. Nudging: A very short guide. Bus. Econ. 2019, 54, 127-129. [CrossRef]

29. Schmidt, K.; Rohden Skov, L.; Guldborg Hansen, P.; Maaloe Jespersen, A.; Perez-Cueto, F.J.A.; Egberg Mikkelsen, B. 20th International Congress of Nutrition: Granada, Spain, September 15-20, 2013. Ann. Nutr. Metab. 2013, 63, 1-1960.

30. Rogers, E.M. Diffusion of Innovations; Free Press of Glencoe: New York, NY, USA, 1962.

31. Fromm, E. The Fear of Freedom; International library of sociology and social reconstruction, 99-0114726-3; Routledge \& Kegan Paul PLC, London: London, UK, 1942.

32. Shiva, V. Monocultures of the Mind: Perspectives on Biodiversity and Biotechnology; Zed: London, UK, 1993; ISBN 1856492184.

33. Diamond, L. Search of Democracy [Elektronisk resurs]; Routledge: London, UK, 2015.

34. Warburton, D. Community and Sustainable Development: Participation in the Future; Earthscan: London, UK, 1998; ISBN 1-85383-530-7.

35. Healey, P. Collaborative Planning in Perspective. Plan. Theory 2003, 2, 101-123. [CrossRef]

36. Cleveland, M.; Cleveland, S. Building Engaged Communities-A Collaborative Leadership Approach. Smart Cities 2018, 1, 155-162. [CrossRef]

37. Samuelsson, K.; Giusti, M.; Peterson, G.D.; Legeby, A.; Brandt, S.A.; Barthel, S. Impact of environment on people's everyday experiences in Stockholm. Landsc. Urban Plan. 2018, 171, 7-17. [CrossRef]

38. Samuelsson, K.; Colding, J.; Barthel, S. Urban resilience at eye level: Spatial analysis of empirically defined experiential landscapes. Landsc. Urban Plan. 2019, 187, 70-80. [CrossRef]

39. Serrano, W. Digital Systems in Smart City and Infrastructure: Digital as a Service. Smart Cities 2018, 1, 134-154. [CrossRef]

40. Hanzl, M. Information technology as a tool for public participation in urban planning: A review of experiments and potentials. Des. Stud. 2007, 28, 289-307. [CrossRef]

41. Bugs, G.; Granell, C.; Fonts, O.; Huerta, J.; Painho, M. An assessment of Public Participation GIS and Web 2.0 technologies in urban planning practice in Canela, Brazil. Cities 2010, 27, 172-181. [CrossRef]

42. Kahila-Tani, M.; Broberg, A.; Kyttä, M.; Tyger, T. Let the Citizens Map_Public Participation GIS as a Planning Support System in the Helsinki Master Plan Process. Plan. Pract. Res. 2016, 31, 195-214. [CrossRef] 
43. Brabham, D.C. Crowdsourcing the Public Participation Process for Planning Projects. Plan. Theory 2009, 8, 242-262. [CrossRef]

44. Barthel, S.; Folke, C.; Colding, J. Social-ecological memory in urban gardens-Retaining the capacity for management of ecosystem services. Glob. Environ. Chang. 2010, 20, 255-265. [CrossRef]

45. Rotondo, F. The U-City Paradigm: Opportunities and Risks for E-Democracy in Collaborative Planning. Futur. Internet 2012, 4, 563-574. [CrossRef]

46. Portmann, E. Rezension "Smart Cities: Big Data, Civic Hackers, and the Quest for a New Utopia". HMD Prax. Wirtsch. 2015, 52, 636-637. [CrossRef]

47. Tilly, C.; Wood, L.J. Social Movements, 1768-2008; Paradigm Publishers: Boulder, CO, USA, 2009; ISBN 978-1-59451-610-8.

48. Katz, V.S.; Gonzalez, C. Toward Meaningful Connectivity: Using Multilevel Communication Research to Reframe Digital Inequality. J. Commun. 2016, 66, 236-249. [CrossRef]

49. Elliott, T.; Earl, J. Online protest participation and the digital divide: Modeling the effect of the digital divide on online petition-signing. New Media Soc. 2018, 20, 698-719. [CrossRef]

50. Robinson, L.; Cotten, S.R.; Ono, H.; Quan-Haase, A.; Mesch, G.; Chen, W.; Schulz, J.; Hale, T.M.; Stern, M.J. Digital inequalities and why they matter. Inf. Commun. Soc. 2015, 18, 569-582. [CrossRef]

51. Colding, J.; Barthel, S. An urban ecology critique on the "Smart City" model. J. Clean. Prod. 2017, 164, 95-101. [CrossRef]

52. Findahl, O. En Miljon Svenskar Vill Inte Använda Internet: En Rapport om Digital Delaktighet; SE: Stockholm, Sweden, 2013; ISBN 978-91-87437-06-9.

53. Reichman, W.E.; Fiocco, A.J.; Rose, N.S. Exercising the brain to avoid cognitive decline: Examining the evidence. Aging Health 2010, 6, 565-584. [CrossRef]

54. Harada, C.N.; Natelson Love, M.C.; Triebel, K.L. Normal Cognitive Aging. Clin. Geriatr. Med. 2013, 29, 737-752. [CrossRef] [PubMed]

55. Hwangbo, H.; Yoon, S.H.; Jin, B.S.; Han, Y.S.; Ji, Y.G. A Study of Pointing Performance of Elderly Users on Smartphones. Int. J. Hum. Comput. Interact. 2013, 29, 604-618. [CrossRef]

56. Sparrow, B.; Liu, J.; Wegner, D.M. Google Effects on Memory: Cognitive Consequences of Having Information at Our Fingertips. Science 2011, 333, 776-778. [CrossRef]

57. Camerer, C.F.; Dreber, A.; Holzmeister, F.; Ho, T.-H.; Huber, J.; Johannesson, M.; Kirchler, M.; Nave, G.; Nosek, B.A.; Pfeiffer, T.; et al. Evaluating the replicability of social science experiments in Nature and Science between 2010 and 2015. Nat. Hum. Behav. 2018, 2, 637-644. [CrossRef]

58. Onnasch, L.; Wickens, C.D.; Li, H.; Manzey, D. Human Performance Consequences of Stages and Levels of Automation. Hum. Factors J. Hum. Factors Ergon. Soc. 2014, 56, 476-488. [CrossRef]

59. Kendeou, P.; van den Broek, P. The effects of prior knowledge and text structure on comprehension processes during reading of scientific texts. Mem. Cognit. 2007, 35, 1567-1577. [CrossRef]

60. Holling, C.S.; Meffe, G.K. Command and Control and the Pathology of Natural Resource Management. Conserv. Biol. 1996, 10, 328-337. [CrossRef]

61. Duijnhoven, H.; Neef, M. Disentangling Wicked Problems: A Reflexive Approach Towards Resilience Governance. In Applications of Systems Thinking and Soft Operations Research in Managing Complexity: From Problem Framing to Problem Solving; Springer: Berlin/Heidelberg, Germany, 2016; pp. 91-106. ISBN 9783319211060.

62. Wilkinson, C.; Porter, L.; Colding, J. Metropolitan planning and resilience thinking-A practitioner's perspective. Crit. Plan. 2010, 17, 2-20.

63. Folke, C. Resilience (Republished). Ecol. Soc. 2016, 21, art44. [CrossRef]

64. Yanow, D. Conducting Interpretive Policy Analysis; Sage: Thousand Oaks, CA, USA, 2000; ISBN 0761908269.

65. Roe, E. Taking Complexity Seriously. Policy Analysis. Triangulation and Sustainable Development; Kluwer: Boston, MA, USA, 1998.

66. Low, B.; Ostrom, E.; Simon, C.; Wilson, J. Redundancy and diversity: Do they influence optimal management? In Navigating Social-ecological Systems: Building Resilience for Complexity and Change; Berkes, F., Colding, J., Folke, C., Eds.; Cambridge University Press: Cambridge, UK, 2003; pp. 83-114.

67. Levin, S.A. Fragile Dominion: Complexity and the Commons; Perseus Books: Cambridge, MA, USA, 1999; ISBN 0-7382-0111-1. 
68. Elmqvist, T.; Folke, C.; Nyström, M.; Peterson, G.; Bengtsson, J.; Walker, B.; Norberg, J. Response diversity, ecosystem change, and resilience. Front. Ecol. Environ. 2003, 1, 488-494. [CrossRef]

69. Leaman, A.; Bordass, B. Sick Building Syndrome; Rostron, J., Ed.; Routledge: London, UK, 2005; ISBN 9780203989524.

70. Graham, S. Disrupted Cities; Routledge: London, UK, 2010; ISBN 9780203894484.

71. Bai, X.; Dawson, R.J.; Ürge-Vorsatz, D.; Delgado, G.C.; Salisu Barau, A.; Dhakal, S.; Dodman, D.; Leonardsen, L.; Masson-Delmotte, V.; Roberts, D.C.; et al. Six research priorities for cities and climate change. Nature 2018, 555, 23-25. [CrossRef]

(C) 2019 by the authors. Licensee MDPI, Basel, Switzerland. This article is an open access article distributed under the terms and conditions of the Creative Commons Attribution (CC BY) license (http://creativecommons.org/licenses/by/4.0/). 